\title{
Exposure to parental and sibling smoking and the risk of smoking uptake in childhood and adolescence: a systematic review and meta-analysis
}

\author{
Jo Leonardi-Bee, Mirriam Lisa Jere, John Britton
}

\section{See Editorial, p 842}

- Additional figures are published online only. To view these files please visit the journal online (http://thorax.bmj. com)

UK Centre for Tobacco Control Studies, Division of

Epidemiology and Public Health, University of Nottingham, UK

Correspondence to Associate Professor Jo Leonardi-Bee, Division of Epidemiology and Public Health, University of Nottingham, Clinical Sciences Building, City Hospital Campus, Hucknall Road, Nottingham NG5 1PB, UK; jo.leonardi-bee@ nottingham.ac.uk

Received 12 October 2010 Accepted 6 January 2011 Published Online First 15 February 2011

\begin{abstract}
Background There is increasing evidence that contact with other smokers, particularly in the family, is a strong determinant of risk of smoking uptake. A systematic review and meta-analysis of the magnitude of these effects is reported.

Methods Studies were identified by searching four databases to March 2009 and proceedings from international conferences. Meta-analyses were performed using random effects, with results presented as pooled ORs with $95 \% \mathrm{Cls}$.

Results 58 studies were included in the meta-analyses. The relative odds of uptake of smoking in children were increased significantly if at least one parent smoked (OR $1.72,95 \% \mathrm{Cl} 1.59$ to 1.86$)$, more so by smoking by the mother (OR 2.19, 95\% Cl 1.73 to 2.79 ) than the father (OR 1.66, 95\% Cl 1.42 to 1.94$)$, and if both parents smoked (OR 2.73, 95\% Cl 2.28 to 3.28). Smoking by a sibling increased the odds of smoking uptake by 2.30 (95\% Cl 1.85 to 2.86$)$ and smoking by any household member by 1.92 (95\% Cl 1.70 to 2.16). After adjusting for overestimation of RRs it is estimated that, in England and Wales, around 17000 young people take up smoking by the age of 15 each year as a consequence of exposure to household smoking.
\end{abstract}

Conclusions Parental and sibling smoking is a strong and significant determinant of the risk of smoking uptake by children and young people and, as such, is a major and entirely avoidable health risk. Children should be protected from exposure to smoking behaviour, especially by family members.

\section{INTRODUCTION}

Approximately 1.1 billion people in the world are current smokers, and this figure is expected to rise to more than 1.6 billion by the year $2025 .{ }^{1}$ Since regular smoking results in a $50 \%$ likelihood of premature death and an average reduction of life expectancy by 10 years, ${ }^{2}$ smoking represents a massive public health problem. Tobacco smoke is powerfully addictive, so experimentation and uptake of smoking which, in developed countries typically occurs in late childhood or adolescence, ${ }^{3}$ is a highly hazardous behaviour. It is crucially important therefore to prevent exposure of young people to factors that increase their risk of smoking uptake.

Various risk factors have been shown to be associated with tobacco use in adolescents, ${ }^{4}$ ranging from individual to social and community and societal factors-including age, sex and socioeconomic status ${ }^{5}$; parental separation ${ }^{6}$ or family conflict $^{7}$; and smoking among peer groups, ${ }^{8-10}$ in feature films ${ }^{11}$ and, perhaps most importantly, among family members. ${ }^{4}$ Smoking in the home is a recognised and entirely avoidable health hazard for children both before and after birth through passive exposure to smoke, ${ }^{12}$ however the influence of family smoking on the risk of smoking uptake and consequent future health of the individual is an aspect that to date has not be systematically reviewed and quantified.

In this paper we have reviewed the available world literature on the relation between smoking by family members and uptake of smoking among children and adolescents, and combined this information in meta-analyses to provide summary estimates of the magnitude of the effects of smoking by different family members. We have also used these estimates to calculate the number of children and young people in England and Wales who take up smoking each year as a result of smoking by others in their household. The work was carried out as part of a more extensive review of the effects of passive smoking in children for the Royal College of Physicians. ${ }^{13}$

\section{METHODS}

\section{Systematic review}

We performed comprehensive searches of four databases (EMBASE, MEDLINE, PsycINFO and CAB Abstracts) from 2000 to March 2009 to identify all epidemiological studies assessing the association between smoking by children (2-12 years of age) and adolescents (13-19 years of age) and exposure to parental smoking (either parent, at least one parent, both parents), household smoking or sibling smoking (search strategies available by request). We also hand-searched conference proceedings from the Society for Research on Nicotine and Tobacco, the UK National Smoking Cessation Conference, the World Conference on Tobacco or Health from 2006 to 2009, as well as reference lists from identified relevant studies and previous narrative reviews. The systematic review was carried out in accordance with the Meta-analysis Of Observational Studies in Epidemiology (MOOSE) guidelines. ${ }^{14}$

One author (MLJ) assessed the eligibility of studies from their titles and abstracts, excluding those that were not relevant. The full texts of eligible papers were assessed independently for eligibility by two authors (MLJ and JL-B) who extracted the data using a data extraction form. Disagreements were resolved through discussion.

No language restrictions were imposed during the searches, but papers written in languages 
other than English were excluded from the meta-analyses. The Newcastle Ottawa Scale ${ }^{15}$ was used to assess the quality of the included studies based on selection, comparability between exposure groups and ascertainment. The a priori chosen score of 7 was used to distinguish high from poorer quality studies.

\section{Meta-analysis}

Dichotomous data were extracted using raw values, crude ORs or adjusted ORs with $95 \%$ CIs. Adjusted ORs were used in preference where available. We performed meta-analyses using random effect models since the effect measures were expected to be heterogeneous. Exposure groupings (eg, any parent smoking) were defined empirically from those used in the studies. Heterogeneity between the studies was assessed using $\mathrm{I}^{2}{ }^{2}{ }^{16}$ Subgroup analyses based on quality (high vs poorer quality) and the definition of smoking status (current vs ever) were used to explore heterogeneity. Owing to disparate categories for the ages of the children and adolescents across the studies, subgroup analysis based on age at outcome was not feasible. Where extreme levels of heterogeneity were seen between the studies $\left(\mathrm{I}^{2} \geq 90 \%\right.$ ), we performed sensitivity analyses to assess the effect of excluding outliers. We also restricted analyses to studies which adjusted for at least three of the following known confounders: age, gender, socioeconomic status, ethnicity, educational achievement, peer smoking and family structure. Publication bias was assessed using funnel plots. Analysis was performed using Review Manager 5.0. ${ }^{17} \mathrm{p}$ Values $<0.05$ were considered statistically significant.

\section{Population attributable fraction estimation}

We estimated the proportion of children who live in a household in which at least one person smokes using data from the Health Survey for England, ${ }^{13}$ and used the formula $\mathrm{p}(\mathrm{OR}-1) /[\mathrm{p}(\mathrm{OR}-$ 1) +1 ], in which $p$ is the proportion of the cohort exposed to passive smoking and OR is the OR for smoking in children or adolescents where a member of the household smokes, to estimate the proportion of children whose smoking is attributable to household smoking exposure. We then used national smoking prevalence data for England and Wales to estimate the number of smokers by age 15 generated as a result of household exposure. Since ORs overestimate true RRs and this effect becomes increasingly relevant as the prevalence of the outcome increases, we also calculated the attributable risk using a lower $R R$ based on an independent estimate that the magnitude of this likely overestimation is of the order of $15 \%{ }^{18}$

\section{RESULTS}

\section{Overview of included studies}

We identified 179 potentially eligible studies published between 2000 and 2009 and excluded 102 after screening the title and abstract. A further 19 studies were excluded from the metaanalyses because the data were not presented in a suitable format for meta-analysis, ${ }^{3}{ }^{19-29}$ the same cohort was used in an already included study ${ }^{30} 31$ or they were published in a non-English language, ${ }^{32-36}$ leaving 58 studies included in the meta-analysis (table 1, figure 1). ${ }^{5} 71037-91$ The majority of the studies were conducted in the USA or Europe and measured adolescent smoking status by self-reports, although two assessed cotinine in saliva. ${ }^{40} 44$ The majority of the included studies reported adjusted estimates, with only three reporting crude estimates. ${ }^{51} 6287$ The quality of the studies ranged from 3 to 8 , with a median score of 6 .

\section{Parental smoking}

Exposure was determined by having one parent who smokes in 14 studies, of which a pooled analysis found that the risk of smoking in adolescence was increased by $62 \%$ (OR 1.62, 95\% CI 1.49 to 1.76; see figure 5 in online supplement) ${ }^{10} 3840424748$ $6571767883-86$ which was independent of quality and the definition of smoking used. The effect was stronger for smoking by the mother (OR 2.19, 95\% CI 1.73 to $2.79 ; 24$ studies $\mathrm{I}^{2}=99 \%$; figure 2$)^{41} 48495155575860-646668697279808287-91$ than the father (OR 1.66, 95\% CI 1.42 to 1.94; 18 studies, $\mathrm{I}^{2}=90 \%$; figure 3). ${ }^{48} 5155575860-647072798087-8991$ Subgroup analysis based on quality found higher magnitudes of effect for higher quality studies for smoking by the mother (higher quality, OR $2.35,95 \%$ CI 1.56 to $3.53,13$ studies); conversely, lower quality studies had a higher pooled magnitude of effect for smoking by the father (low quality, OR 1.94, 95\% CI 1.52 to $2.48,7$ studies) (tests for subgroup differences, $\mathrm{p}<0.0001$ for both comparisons). Studies which defined smoking status in the adolescent as having ever tried smoking found stronger effects (mother, OR 2.76, 95\% CI 1.58 to 4.82, 11 studies; father, OR $1.88,95 \%$ CI 1.47 to $2.40,11$ studies) than those that used current smoking (mother, OR 1.64, 95\% CI 1.36 to 1.96, 11 studies; father, OR $1.45,95 \%$ CI 1.15 to $1.83,6$ studies) (test for subgroup differences, $p<0.0001$ for both comparisons). Sensitivity analyses where studies with outlier results were excluded had marginal effects on the pooled estimates for mother and father smoking. Additionally, sensitivity analyses restricted to studies which adjusted for at least three of the specified confounders had small effects on the pooled estimates for smoking by the mother (OR 2.25, 95\% CI 1.66 to 3.05, 15 studies) and father (OR 1.52, 95\% CI 1.32 to 1.76, 11 studies).

Among children with at least one parent who smoked, the risk of smoking in the child was increased by 1.72 (95\% CI 1.59 to 1.86 ; 10 studies, $\mathrm{I}^{2}=23 \%$, figure 6 in online supplement $)^{7} 39$ 44-46 5354567475 ; if both parents smoked, the risk was increased almost threefold (pooled OR 2.73, 95\% CI 2.28 to 3.28; 15 studies, $\mathrm{I}^{2}=93 \%$, figure 7 in online supplement). ${ }^{20} 424447485765$ 71-7376 78798587 Subgroup analysis showed similar estimates for quality and for the definition used for smoking status. Sensitivity analyses where studies with outlier results were excluded reduced the pooled effects for both parents smoking (OR 2.16, $95 \%$ CI 1.88 to $2.48, \mathrm{I}^{2}=72 \%$, excluded studies, ${ }^{42}{ }^{57}$ Asian and European subgroups ${ }^{78}{ }^{79}$ ). Additionally, sensitivity analyses restricted to studies which adjusted for at least three of the specified confounders had little effect on the pooled estimate for both parents smoking (OR 2.76, 95\% CI 2.20 to 3.47, 11 studies).

\section{Sibling smoking}

A pooled analysis of 23 studies found that the effect of smoking by a sibling (usually defined within the included studies as an older sibling, with the remaining studies defining as any sibling) more than doubled the risk of an adolescent smoking (OR 2.30 $95 \%$ CI 1.85 to 2.86 ; 23 studies, $I^{2}=95 \%$; figure 4). ${ }^{10} 3739404655$ 57-62 $646573747677798087-89$ Subgroup analyses showed higher magnitudes of effect for poorer quality (OR 2.95, 95\% CI 2.09 to 4.18) than for high quality studies (OR $1.87,95 \%$ CI 1.62 to 2.17), and for studies assessing ever tried smoking (OR 2.60, 95\% CI 1.95 to $3.46,10$ studies) (test for subgroup differences, $\mathrm{p}<0.0001$ for both comparisons). Sensitivity analyses where studies with outlier results were excluded had marginal effects on the pooled estimate (OR 2.04, 95\% CI 1.81 to $2.30, \mathrm{I}^{2}=77 \%$, excluded studies ${ }^{57} 5964$ ). Additionally, sensitivity analyses restricted to studies which adjusted for at least three of the 
Table 1 Characteristics of the 58 included studies

\begin{tabular}{|c|c|c|c|c|c|c|}
\hline Study year (reference) & $\begin{array}{l}\text { Adolescents } \\
\text { (n) }\end{array}$ & $\begin{array}{l}\text { Age of } \\
\text { adolescents } \\
\text { (years) }\end{array}$ & Source of sample & $\begin{array}{l}\text { NOS score for } \\
\text { quality }\end{array}$ & Study design & $\begin{array}{l}\text { Confounders } \\
\text { allowed for* }\end{array}$ \\
\hline Asbridge et $a l^{37}$ & 3400 & $13-19$ & $\begin{array}{l}\text { School-based ( } 30 \text { metropolitan schools), Toronto } \\
\text { Youth Crime and Victimisation Survey, Canada }\end{array}$ & 7 & Cross-sectional & $A, B, C, E$ \\
\hline Bauman et $a l^{38}$ & 8273 & $13-17$ & $\begin{array}{l}\text { School-based, National Longitudinal Study of } \\
\text { Adolescent Health, USA }\end{array}$ & 7 & Longitudinal & A \\
\hline Bergamaschi et $a^{39}$ & 2691 & 16 & $\begin{array}{l}\text { School-based (2nd year high school students), } \\
\text { Romagna, Italy }\end{array}$ & 6 & Cross-sectional & A \\
\hline Cornelius et $a l^{41}$ & 567 & 14 & $\begin{array}{l}\text { Family-based survey (from prenatal clinic), Magee } \\
\text { Women's Hospital, Pittsburgh, USA }\end{array}$ & 8 & Longitudinal & $\mathrm{A}, \mathrm{J}$ \\
\hline Den Exter Blockland et $a l^{42}$ & 2206 & $10-14$ & School-based (Dutch youth), The Netherlands & 7 & Cross-sectional & $A, B, C, E$ \\
\hline Elder et al ${ }^{43}$ & 660 & $11-16$ & $\begin{array}{l}\text { School-based, Hispanic adolescents, San Diego, } \\
\text { California, USA }\end{array}$ & 6 & Cross-sectional & $A, B, J$ \\
\hline Fidler et $a l^{44}$ & 650 & $11-16$ & $\begin{array}{l}\text { School-based, (36 schools), HABITS Study, South } \\
\text { London, UK }\end{array}$ & 8 & Longitudinal & $A, B, C, D$ \\
\hline Foster et $a l^{47}$ & 2153 & 14 & Family study, Dartmouth, North England & 6 & Longitudinal & $A, C, J, S$ \\
\hline Gilman et $a l^{48}$ & 559 & $12-17$ & Family study, New England, USA & 7 & Longitudinal & $A, B, D$ \\
\hline Griesbach et al ${ }^{7}$ & 10500 & 15 & $\begin{array}{l}\text { WHO cross-national study of health behaviours, } \\
\text { health and its social context in children and } \\
\text { adolescents, Europe and North America }\end{array}$ & 7 & Cross-sectional & $A, B, C, S$ \\
\hline Griesler et $a l^{49}$ & 1165 & $14-21$ & $\begin{array}{l}\text { National Longitudinal Survey of Youth (NLSY), } \\
\text { African, Hispanic and white mothers and children }\end{array}$ & 7 & Longitudinal & $A, C, D, E, J, S$ \\
\hline Gritz et $a l^{50}$ & 1004 & $10-18$ & $\begin{array}{l}\text { School-based (6 schools), Houston-Galveston, } \\
\text { Texas, USA }\end{array}$ & 6 & Longitudinal & $C, D, J$ \\
\hline Hesketh et $\left.a\right|^{51}$ & 6674 & $13-18$ & School-based, Zhejiang Province, Eastern China & 3 & Cross-sectional & - \\
\hline Hollis et a ${ }^{52}$ & 2526 & $14-17$ & $\begin{array}{l}\text { Clinic-based, adolescent primary care patients in } \\
\text { medical office waiting rooms, Oregon, USA }\end{array}$ & 6 & Cross-sectional & A \\
\hline Jackson $^{53}$ & 1220 & $11-14$ & $\begin{array}{l}\text { School-based ( } 4 \text { middle schools), Central } \\
\text { Carolina, USA }\end{array}$ & 6 & Cross-sectional & $A, B, D$ \\
\hline Kalesan et $a l^{57}$ & 37224 & $11-18$ & School-based (315 schools), Maryland, USA & 6 & Cross-sectional & B \\
\hline Kelishadi et $a^{58}$ & 427 & $12-20$ & Isfanah, Iran & 7 & Case-Control & $B, C, E, S$ \\
\hline Komro et $a^{59}$ & 1282 & $13-16$ & $\begin{array}{l}\text { Community study, Minnesota, Tobacco Free } \\
\text { Future Project (TFFP), USA }\end{array}$ & 6 & Cross-sectional & A \\
\hline Kristajanson et al ${ }^{60}$ & 7430 & $14-16$ & $\begin{array}{l}\text { School-based, youth in Icelandic secondary } \\
\text { schools, Iceland }\end{array}$ & 6 & Cross-sectional & $C, E, J, S$ \\
\hline Malcon et $a^{61}$ & 1187 & $10-19$ & School-based (urban area), Pellet, Southern Brazil & 6 & Cross-sectional & $A, B$ \\
\hline Martini and Sulistyowati ${ }^{62}$ & 1630 & $13-18$ & $\begin{array}{l}\text { School-based, two regions and two cities, East } \\
\text { Java Province, Indonesia }\end{array}$ & 4 & Cross-sectional & - \\
\hline Menezes et a $/^{63}$ & 4452 & $10-12$ & $\begin{array}{l}\text { Community-based, a cohort of children born in } \\
1993 \text { and followed and later sought 2004-5 }\end{array}$ & 7 & Longitudinal & $A, B, C, D, E$ \\
\hline Milton et $a l^{64}$ & 247 & $9-11$ & School-based (6 primary schools), Liverpool, UK & 7 & Longitudinal & $A, B, D, J$ \\
\hline Molyneux et $a^{65}$ & 6522 & $11-16$ & $\begin{array}{l}\text { School-based (10 secondary schools, } 50 \text { state } \\
\text { secondary schools), Nottinghamshire, UK }\end{array}$ & 6 & Cross-sectional & $A, B, C, J$ \\
\hline Molyneux et al ${ }^{10}$ & 2109 & $13-16$ & $\begin{array}{l}\text { School-based ( } 10 \text { secondary schools), from } 50 \\
\text { state public secondary schools, Nottingham, UK }\end{array}$ & 5 & Cross-sectional & $\mathrm{B}, \mathrm{J}$ \\
\hline Moore et $a l^{66}$ & 1246 & $15-16$ & School-based (55 secondary schools), Wales, UK & 6 & Cross-sectional & $A, B, E, J$ \\
\hline Nichols et $a l^{67}$ & 858 & $12-15$ & School-based, (30 schools), New York, USA & 6 & Longitudinal & $A, D$ \\
\hline 0 'Byrne et al ${ }^{68}$ & 816 & 15.1 (mean) & $\begin{array}{l}\text { School-based (2 high schools and } 2 \text { junior high } \\
\text { schools), Kansas City, Metropolitan area, USA }\end{array}$ & 7 & Cross-sectional & $A, B, D$ \\
\hline $0^{\prime}$ Callaghan et $a^{69}$ & 4541 & $5-14$ & $\begin{array}{l}\text { Mater-University, Queensland Study of pregnancy } \\
\text { (MUSP): a cohort of women at first antenatal visit }\end{array}$ & 6 & Longitudinal & $A, C, S$ \\
\hline Ogwell et $a l^{70}$ & 1130 & $12-17$ & $\begin{array}{l}\text { School-based ( } 10 \text { schools from } 209 \text { primary } \\
\text { schools), Nairobi Province, Kenya }\end{array}$ & 7 & Cross-sectional & $A, B, E$ \\
\hline Otten et $a l^{71}$ & 5495 & $11-16$ & School-based (33 schools), The Netherlands & 7 & Longitudinal & $A, B, E$ \\
\hline
\end{tabular}


Table 1 Continued

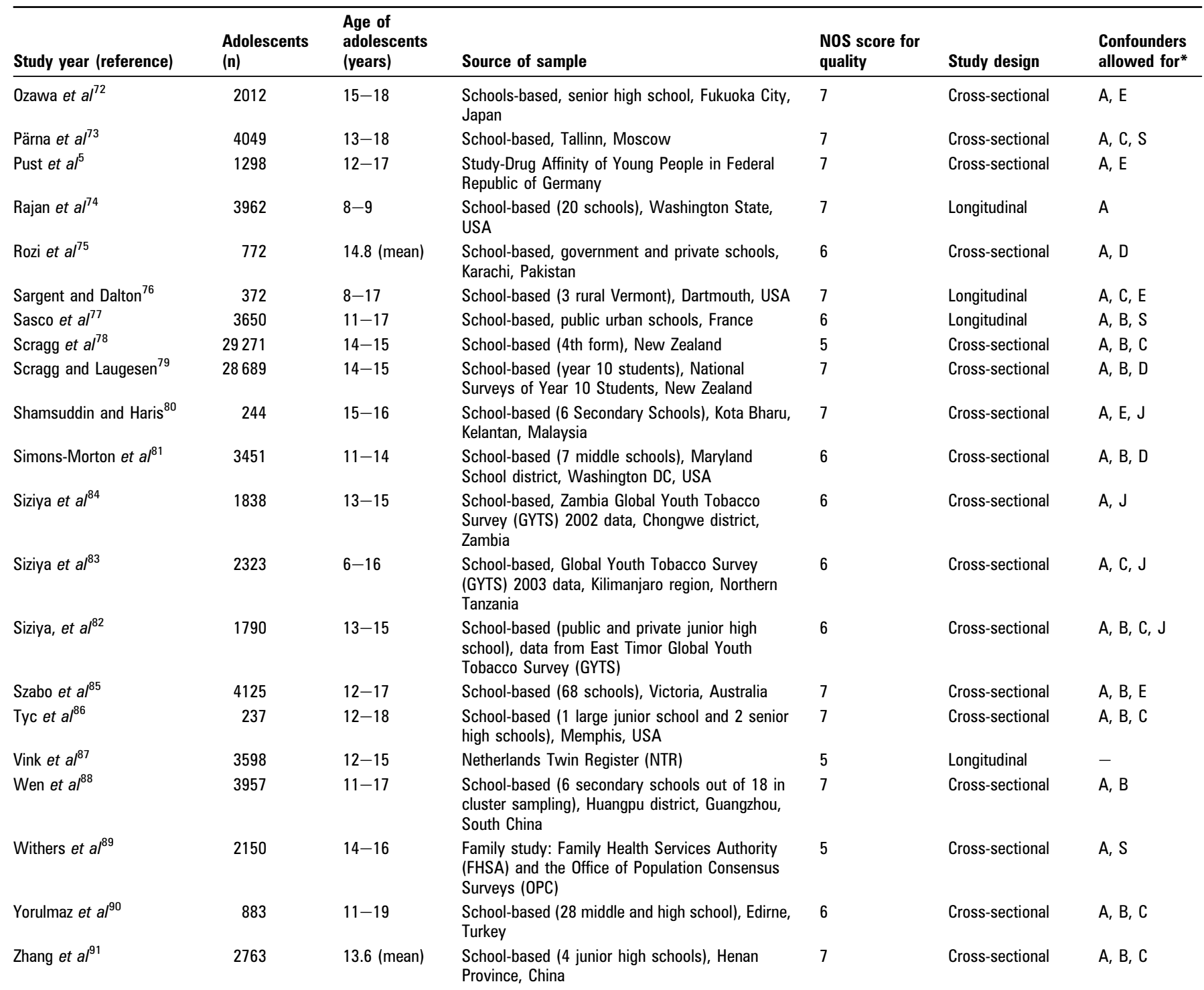

*Potentially important confounders allowed for: A, age; B, gender; C, measure of socioeconomic status; D, ethnicity/race; E, educational achievement; J, peer smoking; S, measure of family structure; -, performed no adjustment.

NOS, Newcastle-Ottawa Scale.

specified confounder effect had similar marginal effects on the pooled estimate (OR 1.94, 95\% CI 1.67 to 2.24 , 12 studies).

\section{Household smoking}

Any household smoking (usually defined as either living with a smoker or that an adult smokes in the home) increased the risk by 1.92 (95\% CI 1.70 to $2.16,12$ studies; $I^{2}=80 \%$; figure 8 in

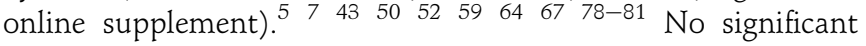
differences in effect size were seen between the subgroup analyses for quality or definition for smoking status (test for subgroup differences, $p=0.86$ and $p=0.17$, respectively). Sensitivity analyses restricted to studies which adjusted for at least three of the specified confounders slightly reduced the pooled estimate (OR $1.69,95 \%$ CI 1.54 to $1.87,8$ studies), but the effect remained highly statistically significant.

\section{Publication bias}

No evidence of publication bias was seen in the funnel plots for the relation between adolescent smoking and either parent smoking, both parents smoking, mother smoking, father smoking, and at least one parent smoking. However, there was some evidence of asymmetry in the funnel plot for sibling smoking and household smoking, where smaller sized studies showing protective effects on the risk of adolescent smoking seemed to be missing from the funnel plots (see figure 9 in online supplement).

\section{Population attributable fraction}

Health survey for England data indicate that, in 2007, around $22 \%$ of children aged up to 15 lived in a household in which someone smokes. ${ }^{13}$ Using the OR for household smoking (1.92) as the estimated RR of smoking in these children, the proportion of smoking uptake among children up to the age of 15 likely to be attributable to exposure to smoking in the home is estimated at 17\%. In 2008 there were about 67500015 -year-old adolescents in England and Wales, ${ }^{92}$ of whom $20 \%$ smoke $^{93}$; a $17 \%$ attributable fraction translates into approximately 23000 new smokers by age 15 arising from exposure to smoking in the home. Allowing for overestimation of the true RR from estimating pooled ORs, ${ }^{18}$ the adjusted estimate of $\mathrm{RR}$ is then 


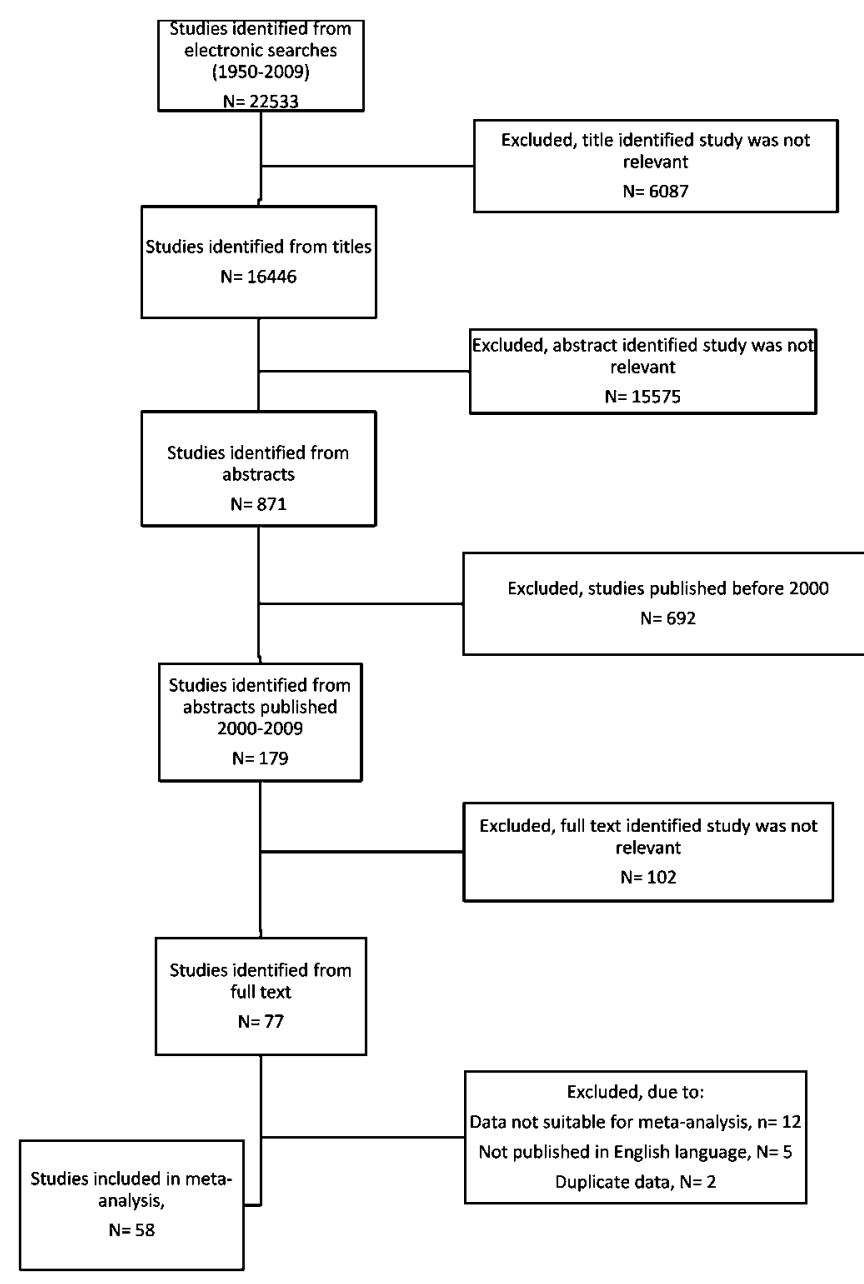

Figure 1 Flow chart of included studies.

approximately 1.67 , the corrected population attributable fraction $13 \%$ and the estimated number of new smokers attributable to household exposure 17000.

\section{DISCUSSION}

This study uses systematic review and meta-analysis methods to provide summary estimates of the effect of living with a family member who smokes on the risk that a child or young person takes up smoking. The analyses confirm that smoking by siblings, parents or other household members-and particularly by parents-is a strong and significant influence on smoking uptake. The effect of individual family member smoking is strongest for smoking by the mother, but is stronger still when both parents smoke, with a near threefold increase in risk. We estimate that around 23000 adolescents who are smoking regularly at the age of 15 in England and Wales are doing so as a consequence of exposure to household smoking. The consequences of smoking uptake in these individuals are likely to include significant morbidity and premature mortality, and also the financial poverty arising from a regular habit which, at 20 cigarettes per day at current UK prices, costs around $£ 2000$ per year. For those who commence smoking at younger age, these impacts are likely to be all the greater since early uptake of smoking is also associated with higher levels of tobacco dependence ${ }^{94}$ and heavier smoking. ${ }^{5}$

The great majority of the studies we assessed relied on selfreported smoking status which has been shown to be a good indicator of true smoking status in general, but may underestimate smoking in adolescents. ${ }^{95}$ This may result in underestimation of the observed effects and also contribute to some of the observed heterogeneity between studies. A limitation of this meta-analysis was that high levels of heterogeneity were observed for some comparisons, which suggests that there are unexplained reasons for variation in the findings between studies over and above chance which may result in potentially misleading summary estimates. We investigated the reasons for heterogeneity by performing subgroup analyses and sensitivity analyses; however, these analyses revealed relatively consistent findings. Generally, the pooled results did not differ appreciably between studies of different methodological quality or in relation to the definition of smoking status of the adolescent. ORs were higher, however, for studies that measured ever having tried smoking, consistent with the fact that a substantial proportion of children and young people experiment with smoking but do not become regular addicted smokers. We assessed the effects on smoking status in adolescence rather than attempting to assess the effect on the stage transitions of tobacco use-where adolescents can be labelled as 'triers', 'experimenters', 'regular users' and 'dependent users' an insufficient number of studies being identified which categorised the stages of smoking. It is therefore difficult to determine at which stages the effects of parental and sibling smoking have more impact. Although inconsistent findings for a dose response association were seen in previous studies, ${ }^{97}$ we found strong evidence of this, where adolescents were at a greater risk of smoking when both parents smoked than when only one parent smoked. We also found that the magnitude of the effect was stronger when the mother smoked than when the father smoked. This finding appears to be more pronounced in recent years, ${ }^{97}$ and there was some evidence of a sex-specific effect where girls were influenced more by maternal than paternal smoking while the opposite applied to boys (data not shown). Further reasons for heterogeneity between the studies could be differences in approaches to adjustment for confounding; however, our sensitivity analyses restricted to studies which adjusted for multiple known confounding factors generally found the pooled results were very similar to the results from the unrestricted analyses. However, the pooled estimate for exposure to any household smoking was reduced from a pooled OR of 1.92 to 1.69 , but the results remained highly statistically significant.

A limitation of our systematic review was that we excluded studies at the full text stage which were written in a nonEnglish language, so the findings of the meta-analyses are biased towards English speaking countries. However, this exclusion criterion only resulted in five papers being excluded (conducted in France, the Netherlands, Slovakia, China and Austria), so the exclusion of these papers is unlikely to have a substantial impact on the conclusions of this study.

In the meta-analysis we estimated pooled ORs since 56 of the 58 included studies reported this measure of effect. Since smoking in adolescents is not rare, our estimated pooled ORs will overestimate the true RRs although, at an estimated $15 \%$, ${ }^{18}$ the magnitude of this effect is small. Thus, allowing for overestimation of the true pooled estimate has marginal effects on the estimated strength of the association. Allowing for the overestimation in the calculation for the population attributable fraction results in an estimated 17000 new smokers by age 15 arising from exposure to smoking in the home.

The importance of this study is that, irrespective of the true magnitude of these effects, it identifies a further and to date 
Figure 2 Mother smoking and the risk of adolescent smoking. Squares represent the estimate of effect and horizontal lines the $95 \%$ Cls from the individual studies. The centre of the diamond represents the pooled $\mathrm{OR}$ and the corner of the diamond the $95 \% \mathrm{Cls}$. ORs $>1$ indicate that exposure to mother smoking increases the risk of adolescent smoking.

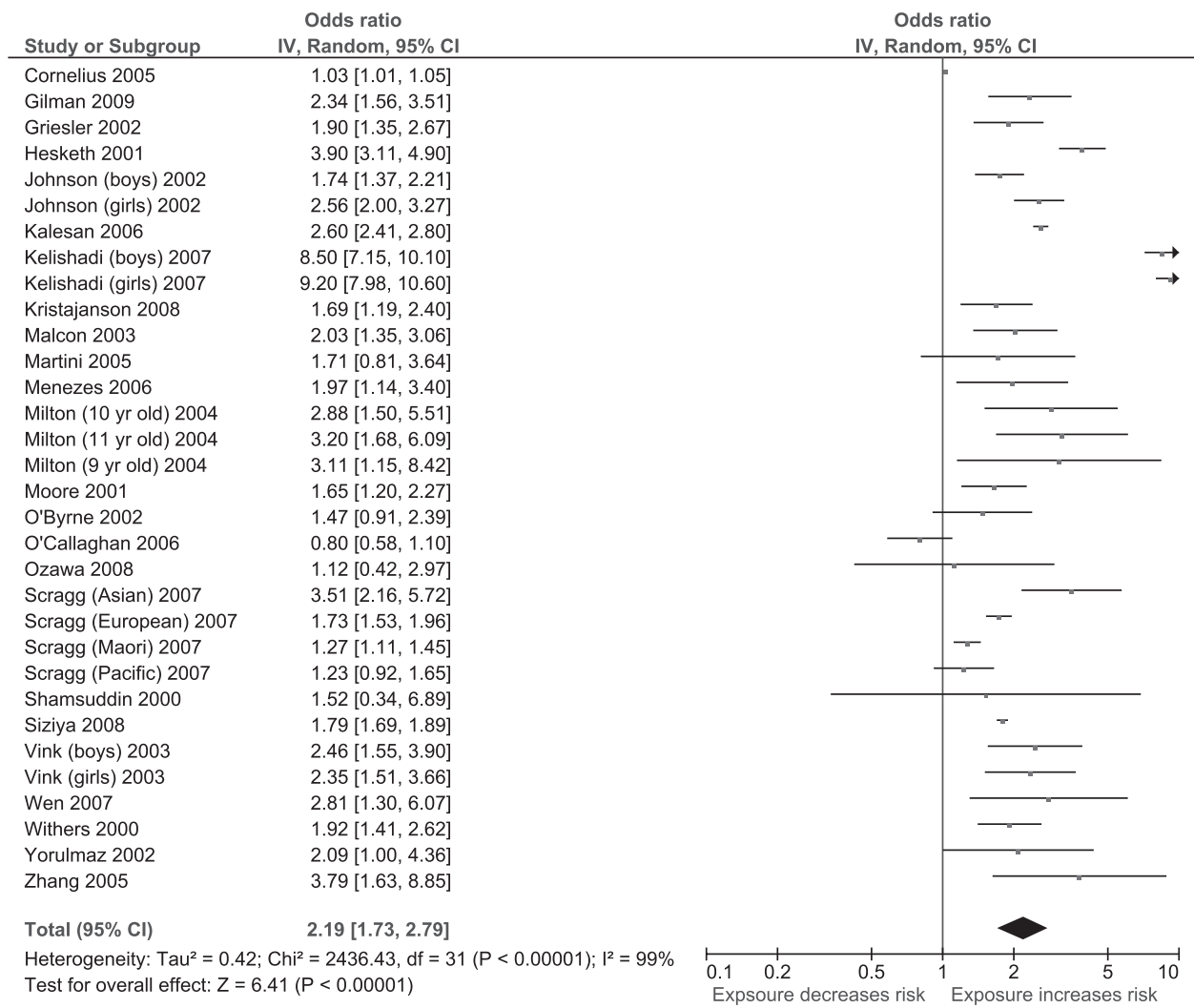

neglected third-party impact of smoking behaviour. The health risks to children and adults arising from passive smoke exposure are now well recognised and extensively documented, ${ }^{12}{ }^{13}$ but arise directly and only from exposure to tobacco smoke. In this instance we identify an impact with the potential for substantial short- and long-term harm to health arising from the availability of cigarettes and/or the role model of smoking behaviour in the family. The number of children potentially affected is substantial, with around 2 million children in the UK living in a household that includes a smoker. This is a massive public health problem in its own right.
Effective measures to prevent smoking are well defined and promoted by the World Health Organization ${ }^{98}$ and include a range of policies that will help to reduce the prevalence of smoking in younger adults-and hence the typical parents of younger children-and thus reduce exposure to smoking behaviour. However, they do not yet address the need to ensure that children grow up in a home that is not only smoke-free-to protect them from the direct health consequences of passive smoking-but also free of smokers-to protect them from the adverse effects of smoking role models since observation of parental smoking behaviour can have profound influences on the
Figure 3 Father smoking and the risk of adolescent smoking. Squares represent the estimate of effect and horizontal lines the $95 \% \mathrm{Cls}$ from the individual studies. The centre of the diamond represents the pooled $\mathrm{OR}$ and the corner of the diamond the $95 \% \mathrm{Cls}$. ORs $>1$ indicate that exposure to father smoking increases the risk of adolescent smoking.

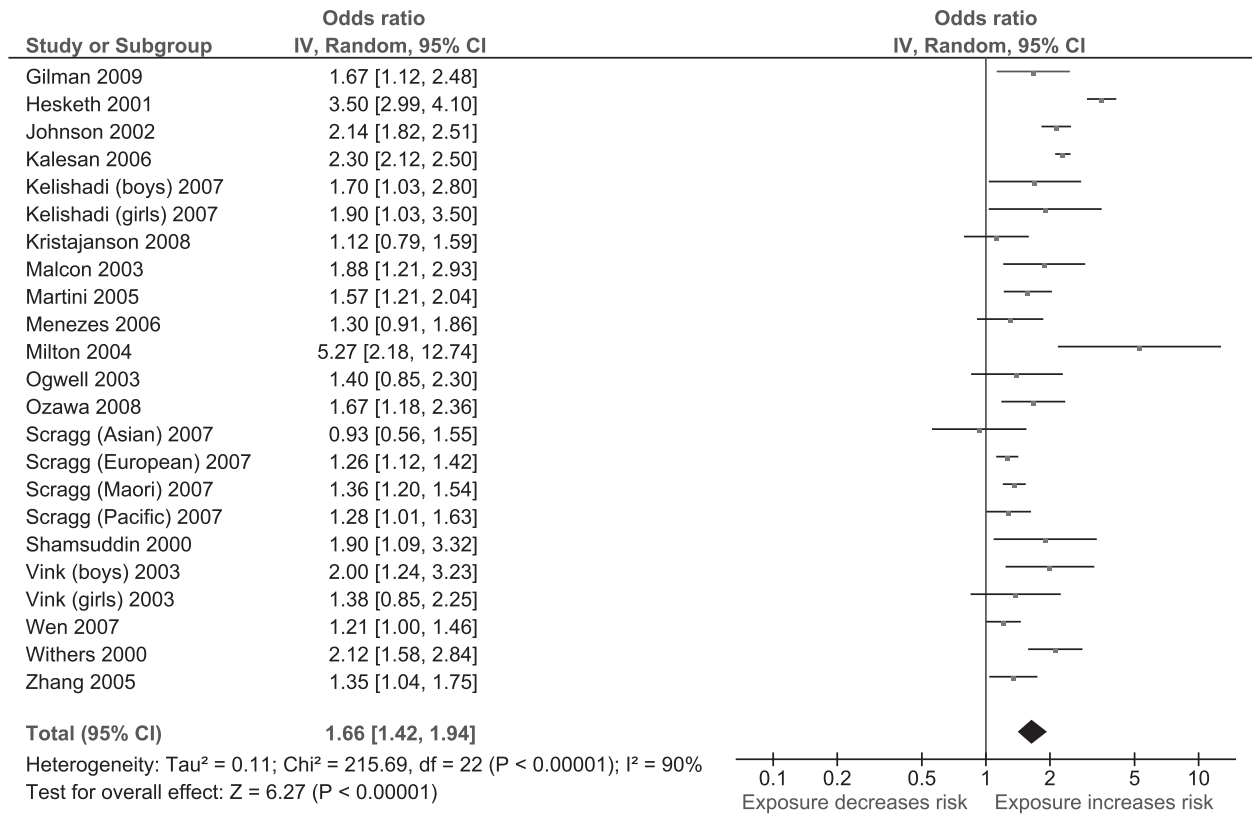


Figure 4 Sibling smoking and the risk of adolescent smoking. Squares represent the estimate of effect and horizontal lines the $95 \%$ Cls from the individual studies. The centre of the diamond represents the pooled $\mathrm{OR}$ and the corner of the diamond the $95 \% \mathrm{Cls}$. ORs $>1$ indicate that exposure to sibling smoking increases the risk of adolescent smoking.

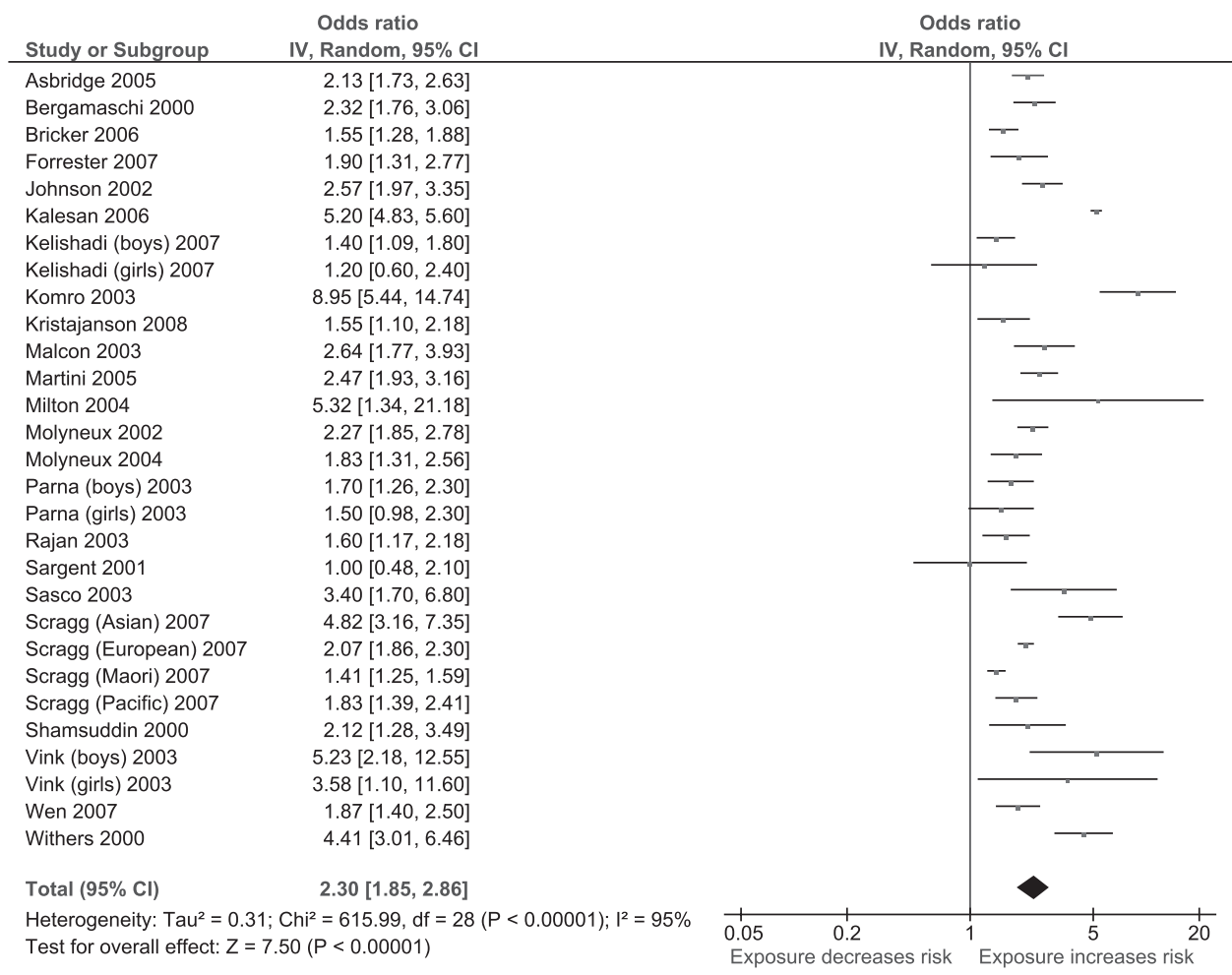

perspectives of preschool children who view this behaviour as appropriate or normative in social situations. ${ }^{99} 100$ Preventing this latter effect will demand further radical changes in public policy and behaviour, and in the acceptability of smoking in places where children are present. Protection of children from this major cause of harm needs to become a high public health priority.

Funding This work was supported by the UK Centre for Tobacco Control Studies (http://www.ukctcs.org) with core funding from the British Heart Foundation, Cancer Research UK, Economic and Social Research Council, Medical Research Council and the Department of Health, under the auspices of the UK Clinical Research Collaboration; and by project grant C1512/A11160 from Cancer Research UK. The study sponsor had no role in study design; in the collection, analysis and interpretation of data; in the writing of the report; or in the decision to submit the paper for publication.

\section{Competing interests None.}

Contributors $\mathrm{JL}-\mathrm{B}$ contributed to the conception and design, analysis and interpretation of data, drafted and critically revised the article for important intellectual content, approved the final version to be published, had access to all of the data in the study and had final responsibility for the decision to submit for publication. MLJ contributed to the analysis and interpretation of the data, drafted the article and approved the final version to be published. JB contributed to the conception and design, critically revised the article for important intellectual content and approved the final version to be published. JL-B is the guarantor

Provenance and peer review Not commissioned; externally peer reviewed.

\section{REFERENCES}

1. World Bank. Curbing the Epidemic Governments and the Economics of Tobacco Control. Washington, DC: World Bank, 1999.

2. Doll R, Peto R, Boreham J, et al. Mortality in relation to smoking: 50 years observations on male British doctors. BMJ 2004:328:1519-33.

3. Hill KG, Hawkins JD, Catalano RF, et al. Family influences on the risk of daily smoking initiation. J Adolesc Health 2005;37:202-10.

4. Geckova A, van Dijk JP, van Ittersum-Gritter T, et al. Determinants of adolescents' smoking behaviour: a literature review. Cent Eur J Public Health 2002;10:79-87.

5. Pust S, Mohnen SM, Schneider S. Individual and social environment influences on smoking in children and adolescents. Public Health 2008;122:1324-30.

6. Kestila L, Koskinen S, Martelin T, et al. Influence of parental education, childhood adversities, and current living conditions on daily smoking in early childhood. Eur $\mathrm{J}$ Public Health 2006;16:617-26.
7. Griesbach D, Amos A, Currie C. Adolescent smoking and family structure in Europe. Soc Sci Med 2003:56:41-52.

8. de Vries H, Engels R, Kremers S, et al. Parents' and friends' smoking status as predictors of smoking onset: findings from six European countries. Health Educ Res 2003;18:627-36.

9. Kobus K. Peers and adolescent smoking. Addiction 2003;98:37-55

10. Molyneux A, Lewis S, Antoniak M, et al. Prospective study of the effect of exposure to other smokers in high school tutor groups on the risk of incident smoking in adolescence. Am J Epidemiol 2004;159:127-32.

11. Wellman RJ, Sugarman DB, DiFranza JR, et al. The extent to which tobacco marketing and tobacco use in films contribute to children's use of tobacco. A metaanalysis. Arch Pediatr Adolesc Med 2006;160:1285-96.

12. Tobacco Advisory Group. Going Smoke-free. The Medical Case for Clean Air in the Home, at Work and in Public Places. Report on Passive Smoking by the Tobacco Advisory Group of the Royal College of Physicians. London: Royal College of Physicians, 2005

13. Tobacco Advisory Group. Passive smoking and children. Report by the Tobacco Advisory Group. London: Royal College of Physicians, 2010.

14. Stroup DF, Berlin JA, Morton SC, et al. Meta-analysis of observational studies in epidemiology: a proposal for reporting. Meta-analysis Of Observational Studies in Epidemiology (MOOSE) Group. J Am Med Assoc 2000;283:2008-12.

15. Wells G, Shea B, O'Connell D, et al. Newcastle-Ottawa Scale (NOS) for Assessing the Quality of Non-randomised Studies in Meta-analysis. http://www.ohri.ca/ programs/clinical epidemiology/oxford.htm (accessed Mar 2009).

16. Higgins JP, Thompson SG, Deeks JJ, et al. Measuring inconsistency in metaanalyses. BMJ 2003:327:557-60

17. The Nordic Cochrane Centre. Review Manager (RevMan). Copenhagen: The Cochrane Collaboration, 2008.

18. Davies HT, Crombie IK, Tavakoli M. When can odds ratios mislead? BMJ 1998; 316:989

19. Andersen MR, Leroux BG, Marek PM, et al. Mothers' attitudes and concerns about their children smoking: do they influence kids? Prev Med 2002; 34:198-206

20. Bard DE, Rodgers JL. Sibling influence on smoking behavior: a within-family look at explanations for a birth-order effect. J Appl Soc Psychol 2003:33:1773-95.

21. Bricker JB, Peterson AV, Andersen MR, et al. Parents' and older siblings' smoking during childhood: changing influences on smoking acquisition and escalation over the course of adolescence. Nicotine Tob Res 2007; 9:915-26.

22. den Exter Blockland EA, Hale WW 3rd, Meeus W, et al. Parental support and control and early adolescent smoking: a longitudinal study. Subst Use Misuse 2007:42:2223-32.

23. Effuso L, Barra D, Del Castello $E$, et al. Factors influencing the age at which adolescents start smoking. A comparison between a big and a small city. Ital Heart $J$ 2002;3:64-8.

24. Faucher MA. Why do girls smoke? A path analysis of mother-daughter connectedness, self-concept, race/ethnicity and smoking behavior of mothers and 
friends as contributors to smoking behavior in teenage girls. Diss Abstr Int B Sci Eng 2002; September

25. Harakeh Z, Engles RCME, Vermulst AA, et al. The influence of best friends and siblings on adolescent smoking: a longitudinal study. Psychol Health 2007;22:269-89.

26. Leiner M, Medina I, Tondapu SR, et al. Smoking status of adolescents in two countries and the impact of the smoking status of mother, father, grandparents, and siblings. J Sch Health 2008;78:129-30.

27. Ma GX, Shive $\mathrm{S}$, Legos $\mathrm{P}$ et al. Ethnic differences in adolescent smoking behaviors, source of tobacco, knowledge and attitudes towards restriction policies. Addict Behav 2003;28:249-68.

28. Madarasová Gecková A, Stewart R, van Dijk JP, et al. Influence of socioeconomic status, parents and peers on smoking behavior of adolescents. Eur Addict Res 2005;11:204-9.

29. Otten R, Engles RCME, van den Eijnden RJJM. General parenting, anti-smoking socialization and smoking onset. Health Educ Res 2008;23:859-69.

30. Menezes AMB, Hallal PC, Horta BL. Early determinants of smoking in adolescence: a prospective birth cohort study. Cad Saúde Pública 2007;23:347-54.

31. Zhang L, Wang W, Zhao 0 , et al. Psychosocial predictors of smoking among secondary school students in Henan, China. Health Educ Res 2000;15:415-22.

32. Courtois R, Caudrelier N, Legay E, et al. Influence parentale (dépendance tabagique et styles éducatifs) sur la consommation et la dépendance tabagique de leur adolescent. Médicale 2007:36:1341-9.

33. Den Exter Blokland E, Engels RCME, Hale WW III, et al. Parental smoking cessation and smoking onset among early adolescents. Gedrag Gezondheid: Tijdschr Psychologie Gezondheid 2002;30:313-26.

34. Geckova A, Pudelsky M, van Dijk JP. Parental influence on smoking, alcohol consumption and sports activities of adolescents. Ceska Slov Psychiatr 2000;96:406-10.

35. Xiaoyi F, Danhua L. Prevention and intervention of adolescents smoking behavior. Acta Psychologica Sinica 2003;35:379-86.

36. Zidek T, Haidinger G, Zacharasiewicz A, et al. [Prevalence of smoking habits of Upper Austria students of the 7th and 8th grade and effect of smoking habits of family and peers]. Soz Praventivmed 2000:45:174-81.

37. Asbridge M, Tanner J, Wortley S. Ethno-specific patterns of adolescent tobacco use and the mediating role of acculturation, peer smoking, and sibling smoking. Addiction 2005;100:1340-51.

38. Bauman KE, Carver K, Gleiter K. Trends in parent and friend influence during adolescence. The case of adolescent cigarette smoking. Addict Behav 2001;26:349-61

39. Bergamaschi A, Gambi A, Gentilini F, et al. Tobacco smoking among high school students in Romagna (Italy) and evaluation of a prevention campaign. Subst Use Misuse 2000;35:1277-95.

40. Bricker JB, Peterson AV, Leroux BG, et al. Prospective prediction of children's smoking transitions: role of parents' and older siblings' smoking. Addiction 2006;101:128-36.

41. Cornelius MD, Leech SL, Goldschmidt L, et al. Is prenatal tobacco exposure a risk factor for early adolescent smoking? A follow-up study. Neurotoxicol Teratol 2005; 27:667-76

42. den Exter Blockland EA, Engels RC, Hale WW 3rd, et al. Lifetime parental smoking history and cessation and early adolescent smoking behavior. Prev Med 2004;38:359-68.

43. Elder JP, Campbell NR, Litrownik AJ, et al. Predictors of cigarette and alcohol susceptibility and use among Hispanic migrant adolescents. Prev Med 2000;31:115-23

44. Fidler JA, West R, van Jaarsveld CHM, et al. Smoking status of step-parents as a risk factor for smoking in adolescence. Addiction 2008;103:496-501.

45. Fisher LB, Winickoff JP, Camargo CA, et al. Household smoking restrictions and adolescent smoking. Am J Health Promot 2007;22:15-21.

46. Forrester K, Biglan A, Severson $\mathbf{H H}$, et al. Predictors of smoking onset over two years. Nicotine Tob Res 2007:9:1259-67.

47. Foster SE, Jones DJ, Olson AL, et al. Family socialization of adolescent's selfreported cigarette use: the role of parents' history of regular smoking and parenting style. J Pediatr Psychol 2007:32:481-93.

48. Gilman SE, Rende R, Boergers J, et al. Parental smoking and adolescent smoking initiation: an intergenerational perspective on tobacco control. Pediatrics 2009:123: e274-81.

49. Griesler PC, Kandel DB, Davies M. Ethnic differences in predictors of initiation and persistence of adolescent cigarette smoking in the National Longitudinal Survey of Youth. Nicotine Tob Res 2002;4:79-93.

50. Gritz ER, Prokhorov AV, Hudmon KS, et al. Predictors of susceptibility to smoking and ever smoking: a longitudinal study in a triethnic sample of adolescents. Nicotine Tob Res 2003;5:493-506.

51. Hesketh T, Ding QJ, Tomkins A. Smoking among youths in China. Am J Public Health 2001:91:1653-5.

52. Hollis JF, Polen MR, Lichtenstein E, et al. Tobacco use patterns and attitudes among teens being seen for routine primary care. Am J Health Promot 2003:17:231-9.

53. Jackson C. Perceived legitimacy of parental authority and tobacco and alcohol use during early adolescence. J Adolesc Health 2002;31:425-32.

54. Jackson C, Dickinson D. Cigarette consumption during childhood and persistence of smoking through adolescence. Arch Pediatr Adolesc Med 2004;158:1050-6.
55. Johnson CC, Li D, Perry CL, et al. Fifth through eighth grade longitudinal predictors of tobacco use among a racially diverse cohort: CATCH. J Sch Health 2002; 72:58-64

56. Johnson CC, Myers L, Webber LS, et al. Profiles of the adolescent smoker: models of tobacco use among 9th grade high school students: Acadiana Coalition of Teens against Tobacco (ACTT). Prev Med 2004;39:551-8.

57. Kalesan B, Stine J, Alberg AJ. The joint influence of parental modeling and positive parental concern on cigarette smoking in middle and high school students. J Sch Health 2006:76:402-7: quiz 438-9.

58. Kelishadi R, Mokhtari MR, Tavasoli AA, et al. Determinants of tobacco use among youths in Isfahan, Iran. Int J Public Health 2007;52:173-9.

59. Komro KA, McCarty MC, Forster JL, et al. Parental, family, and home characteristics associated with cigarette smoking among adolescents. Am J Health Promot 2003:17:291-9.

60. Kristjansson AL, Sigfusdottir ID, Allegrante JP, et al. Social correlates of cigarette smoking among Icelandic adolescents: a population-based cross-sectional study. BMC Public Health 2008:8:86

61. Malcon MC, Menezes AM, Maia Mde F, et al. [Prevalence of and risk factors for cigarette smoking among adolescents in South America: a systematic literature review]. Pan Am J Public Health 2003:13:222-8.

62. Martini S, Sulistyowati M. The determinants of smoking behavior among teenagers in East Java Province, Indonesia. In: Health, Nutrition and Population (HNP) Economics of Tobacco Control Discussion Paper no 32, 2005

63. Menezes AMB, Goncalves H, Anselmi L, et al. Smoking in early adolescence: evidence from the 1993 Pelotas (Brazil) Birth Cohort Study. J Adolesc Health 2006:39:669-77.

64. Milton B, Cook PA, Dugdill L, et al. Why do primary school children smoke? A longitudinal analysis of predictors of smoking uptake during pre-adolescence. Public Health 2004; 118:247-55.

65. Molyneux A, Lewis S, Antoniak M, et al. Is smoking a communicable disease? Effect of exposure to ever smokers in school tutor groups on the risk of incident smoking in the first year of secondary school. Tob Control 2002;11:241-5.

66. Moore L, Roberts C, Tudor-Smith C. School smoking policies and smoking prevalence among adolescents: multilevel analysis of cross-sectional data from Wales. Tob Control 2001;10:117-23.

67. Nichols TR, Birnbaum AS, Birnel S, et al. Perceived smoking environment and smoking initiation among multi-ethnic urban girls. J Adolesc Health 2006;38:369-75.

68. O'Byrne KK, Haddock CK, Poston WSC, et al. Parenting style and adolescent smoking. J Adolesc Health 2002;30:418-25.

69. O'Callaghan FV, O'Callaghan M, Najman JM, et al. Prediction of adolescent smoking from family and social risk factors at 5 years, and maternal smoking in pregnancy and at 5 and 14 years. Addiction 2006;101:282-90.

70. Ogwell AE, Astrom AN, Haugejorden 0. Socio-demographic factors of pupils who use tobacco in randomly-selected primary schools in Nairobi province, Kenya. East Afr Med J 2003;80:235-41.

71. Otten R, Engels RC, van de Ven MO, et al. Parental smoking and adolescent smoking stages: the role of parents' current and former smoking, and family structure. J Behav Med 2007;30:143-54.

72. Ozawa M, Washio M, Kiyohara C. Factors related to starting and continuing smoking among senior high school boys in Fukuoka, Japan. Asian Pac J Cancer Prev 2008; 9:239-45

73. Pärna K, Rahu K, Fischer K, et al. Smoking and associated factors among adolescents in Tallinn, Helsinki and Moscow: a multilevel analysis. Scand J Public Health 2003;31:350-8.

74. Rajan KB, Leroux BG, Peterson AV, et al. Nine-year prospective association between older siblings' smoking and children's daily smoking. J Adolesc Health 2003:33:25-30.

75. Rozi S, Akhtar S, Ali S, et al. Prevalence and factors associated with current smoking among high school adolescents in Karachi, Pakistan. Southeast Asian J Trop Med Public Health 2005:36:498-504.

76. Sargent JD, Dalton M. Does parental disapproval of smoking prevent adolescents from becoming established smokers? Pediatrics 2001;108:1256-62.

77. Sasco AJ, Merrill RM, Benhaim-Luzon V, et al. Trends in tobacco smoking among adolescents in Lyon, France. Eur J Cancer 2003;39:496-504.

78. Scragg R, Laugesen M, Robinson E. Parental smoking and related behaviours influence adolescent tobacco smoking: results from the 2001 New Zealand national survey of 4th form students (see comment). NZ Med J 2003;116:U707.

79. Scragg $\mathbf{R}$, Laugesen M. Influence of smoking by family and best friend on adolescent tobacco smoking: results from the 2002 New Zealand national survey of year 10 students. Aust NZ J Public Health 2007;31:217-23.

80. Shamsuddin K, Haris MA. Family influence on current smoking habits among secondary school children in Kota Bharu, Kelantan. Singapore Med J 2000;41:167-71.

81. Simons-Morton B, Haynie DL, Crump AD, et al. Peer and parent influences on smoking and drinking among early adolescents. Health Educ Behav 2001:28:95-107.

82. Siziya S, Muula AS, Rudatsikira E. Prevalence and correlates of current cigarette smoking among adolescents in East Timor-Leste. Indian Pediatr 2008;45:963-8.

83. Siziya S, Ntata PR, Rudatsikira $E$, et al. Sex differences in prevalence rates and predictors of cigarette smoking among in-school adolescents in Kilimanjaro, Tanzania. Tanzan Health Res Bull 2007;9:190-5. 
84. Siziya S, Rudatsikira E, Muula AS, et al. Predictors of cigarette smoking among adolescents in rural Zambia: results from a cross sectional study from Chongwe district. Rural Remote Health 2007;7:728.

85. Szabo E, White V, Hayman J. Can home smoking restrictions influence adolescents' smoking behaviors if their parents and friends smoke? Addict Behav 2006; 31:2298-303.

86. Tyc VL, Hadley W, Allen D, et al. Predictors of smoking intentions and smoking status among nonsmoking and smoking adolescents. Addict Behav 2004:29:1143-7.

87. Vink JM, Willemsen G, Boomsma DI. The association of current smoking behavior with the smoking behavior of parents, siblings, friends and spouses. Addiction 2003; 98:923-31.

88. Wen X, Chen W, Muscat JE, et al. Modifiable family and school environmental factors associated with smoking status among adolescents in Guangzhou, China. Prev Med 2007:45:189-97.

89. Withers NJ, Low JL, Holgate ST, et al. Smoking habits in a cohort of UK adolescents. Respir Med 2000:94:391-6.

90. Yorulmaz F, Akturk Z, Dagdeviren N, et al. Smoking among adolescents: relation to school success, socioeconomic status nutrition and self-esteem. Swiss Med Wkly 2002; 132:449-54.

91. Zhang L, Wang WF, Zhou G. A cross-sectional study of smoking risk factors in junior high school students in Henan, China. Southeast Asian J Trop Med Public Health 2005;36:1580-4.
92. Office for National Statistics. Mortality Statistics-Deaths Registered in 2008 London: Office for Public Sector Information. 2009. http://www.statistics.gov.uk/ statbase/Product.asp?vInk=15096

93. Health and Social Care Information Centre. Drug Use, Smoking and Drinking among Young People in England in 2008. London: Health and Social Care Information Centre, 2009

94. Huang HL, Hsu CC, Magnus JH, et al. Perceived smoking prevalence at school-leve and children's smoking initiation: a multi-level analysis of a cross-sectional data in Taiwan. Health Policy 2008;86:213-21.

95. Newell S, Girgis A, Sanson-Fisher R. The accuracy of self-reported health behaviors and risk factors relating to cancer and cardiovascular disease in the general population: a critical review. Am J Prev Med 1999;17:211-29.

96. Mayhew KP, Flay BR, Mott JA. Stages in the development of adolescent smoking Drug Alcohol Depend 2000;59:S61-81.

97. Avenevoli S, Merikangas KR. Familial influences on adolescent smoking. Addiction 2003;98:1-20.

98. World Health Organization. WHO Framework Convention on Tobacco Control Geneva: World Health Organization, 2003.

99. Dalton MA, Bernhardt AM, Gibson JJ, et al. Use of cigarettes and alcohol by preschoolers while role-playing as adults. Arch Pediatr Adolesc Med 2005;159:854-9.

100. de Leeuw RNH, Engles RCME, Scholte RHJ. Parental smoking and pretend smoking in young children. Tob Control 2010;19:200-5.

\section{Journal club}

\section{Genetic susceptibility and resistance to tuberculosis}

This study investigated possible biomarkers of susceptibility and resistance to Mycobacterium tuberculosis, identifying gene expression profiles associated with active tuberculosis (TB). Among a South African cohort, genome-wide transcription profiles of whole blood were obtained from 33 TB patients, 34 healthy donors latently infected with $M$ tuberculosis (LTBI) and 9 healthy non-infected donors (NIDs). Cluster analysis of genes demonstrated pronounced differences among TB patients compared with the LBTI and NID groups, with no significant difference in clustering between the LBTI and NID groups.

Reverse transcriptase PCR identified Fc $\gamma$ receptor 1B (FCGR1B) as the most strongly differentially expressed gene in the TB group compared to LBTI. This gene, combined with four other most prominently differentiated genes-CD64, Lactoferrin, guanylate binding protein 5 and Granzyme A-allowed discrimination between TB and LTBI groups with a sensitivity of $94 \%$ (30/32 patients) and specificity of $97 \%$ (33/34 patients). Functional annotation clustering demonstrated distinct differences between TB and LBTI groups with increased expression of macrophage-associated genes and reduced expression of natural killerassociated genes as well as reduced apoptosis in TB patients compared to the LBTI group.

This research demonstrates the importance of genetic control over the innate immune system in the development of active TB. Defining a genetic biosignature of resistance or susceptibility to $M$ tuberculosis identifies targets for future drugs and vaccines, an approach critically important in reducing the significant burden of $\mathrm{TB}$ disease worldwide.

Maertzdorf J, Repsilber D, Parida SK, et al. Human gene expression profiles of susceptibility and resistance in tuberculosis. Genes Immun 2011;12:15-22.

\section{Natalie Settle}

Correspondence to Natalie Settle, Department of Accident and Emergency, Watford General Hospital, Vicarage Road, Watford WD18 0HB, UK; nataliesettle@doctors.org.uk

Published Online First 30 March 2011

Thorax 2011;66:855. doi:10.1136/thoraxjnl-2011-200112 